University of Nebraska - Lincoln

DigitalCommons@University of Nebraska - Lincoln

Agronomy \& Horticulture - Faculty Publications

Agronomy and Horticulture Department

2-1-2006

\title{
Acidification of soil in a dry land winter wheat-sorghum/corn- fallow rotation in the semiarid U.S. Great Plains
}

\author{
David D. Tarkalson \\ University of Nebraska-Lincoln, david.tarkalson@ars.usda.gov \\ Jose O. Payero \\ University of Nebraska-Lincoln, jpayero@clemson.edu \\ Gary W. Hergert \\ University of Nebraska-Lincoln, ghergert1@unl.edu \\ Kenneth G. Cassman \\ University of Nebraska-Lincoln, kcassman1@unl.edu
}

Follow this and additional works at: https://digitalcommons.unl.edu/agronomyfacpub

Part of the Plant Sciences Commons

Tarkalson, David D.; Payero, Jose O.; Hergert, Gary W.; and Cassman, Kenneth G., "Acidification of soil in a dry land winter wheat-sorghum/corn-fallow rotation in the semiarid U.S. Great Plains" (2006). Agronomy \& Horticulture -- Faculty Publications. 134.

https://digitalcommons.unl.edu/agronomyfacpub/134

This Article is brought to you for free and open access by the Agronomy and Horticulture Department at DigitalCommons@University of Nebraska - Lincoln. It has been accepted for inclusion in Agronomy \& Horticulture -Faculty Publications by an authorized administrator of DigitalCommons@University of Nebraska - Lincoln. 
Published in Plant and Soil 283 (2006), pp. 367-379; doi 10.1007/s11104-006-0027-y

http://www.springerlink.com/content/0032-079X Copyright (C) 2006 Springer. Used by permission.

A contribution of the University of Nebraska Agricultural Research Division, Lincoln, NE 68583. Journal series No. 15120.

Submitted December 10, 2005; accepted February 1, 2006.

\title{
Acidification of soil in a dry land winter wheat-sorghum/corn-fallow rotation in the semiarid U.S. Great Plains
}

\author{
David D. Tarkalson, ${ }^{1,5}$ José O. Payero, ${ }^{2}$ Gary W. Hergert, ${ }^{3}$ and Kenneth G. Cassman ${ }^{4}$ \\ ${ }^{1}$ Agronomy and Horticulture Department, West Central Research and Extension Center, University of Nebraska- \\ Lincoln, North Platte, NE 69101, USA. \\ ${ }^{2}$ Department of Biological Systems Engineering, West Central Research and Extension Center, University of \\ Nebraska-Lincoln, North Platte, NE 69101, USA. \\ ${ }^{3}$ Agronomy and Horticulture Department, Panhandle Research and Extension Center, University of Nebraska- \\ Lincoln, Scottsbluff, NE 693, USA. \\ ${ }^{4}$ Agronomy and Horticulture Department, University of Nebraska-Lincoln, Lincoln, NE 6858, USA. \\ ${ }^{5}$ Corresponding author: fax 308 532-3823; email dtarkalson2@unl.edu
}

\begin{abstract}
Soil $\mathrm{pH}$ is decreasing in many soils in the semiarid Great Plains of the United States under dry land no-till (NT) cropping systems. This study was conducted to determine the rate of acidification and the causes of the acidification of a soil cropped to a winter wheat (Triticum aestivum L.)-grain sorghum [Sorghum bicolor (L.) Moench]/corn (Zea mays L.)-fallow rotation (W-S/C-F) under NT. The study was conducted from 1989 to 2003 on soil with a long-term history of either continuous NT management [NT(LT)] (1962-2003) or conventional tillage (CT) (1962-1988) then converted to NT [NT(C)] (1989-2003). Nitrogen was applied as ammonium nitrate (AN) at a rate of $23 \mathrm{~kg} \mathrm{~N} \mathrm{ha}^{-1}$ in 1989 and as urea ammonium nitrate (UAN) at an average annual rate of $50 \mathrm{~kg} \mathrm{~N} \mathrm{ha}^{-1}$ from 1990 to 2003 for both NT treatments. Soil samples were collected at depth increments of $0-5,5-10,10-15$, and $15-30 \mathrm{~cm}$ in the spring of 1989 and 2003 . Acidification rates for the NT(LT) and NT(C) treatments were 1.13 and $1.48 \mathrm{kmol} \mathrm{H}^{+} \mathrm{ha}^{-1} \mathrm{yr}^{-1}$ in the $0-30 \mathrm{~cm}$ depth, respectively. The amount of $\mathrm{CaCO}_{3}$ needed to neutralize the acidification is 57 and $74 \mathrm{~kg} \mathrm{ha}^{-1} \mathrm{yr}^{-1}$ for the NT(LT) and NT(C) treatments, respectively. A proton budget estimated by the Helyar and Porter [1989, Soil Acidity and Plant Growth, Academic Press] method indicated that $\mathrm{NO}_{3}{ }^{-}$leaching from the $30 \mathrm{~cm}$ depth was a primary cause of long-term acidification in this soil. Nitrate leaching accounted for 59 and $66 \%$ of the $\mathrm{H}^{+}$from the acid causing factors for NT(LT) and NT(C) treatments, respectively. The addition of crop residues to the soil neutralized 62 and $47 \%$ of the acidity produced from the leaching of $\mathrm{NO}_{3}^{-}$, and 37 and $31 \%$ of the acid resulting from $\mathrm{NO}_{3}{ }^{-}$leaching and the other acid-causing constituents for the NT(LT) and NT(C) treatments, respectively. These results document that surface soils in dry land W-S/C-F rotations under NT are acidifying under current management practices. Improved management to increase nitrogen uptake efficiency from applied fertilizer would help reduce the rate of acidification. The addition of lime materials to prevent negative impacts on grain yields may be necessary in the future under current management practices.
\end{abstract}

Keywords: acidification, dryland, nitrogen fertilizers, organic anions, proton budget

\section{Introduction}

The $\mathrm{pH}$ of many soils under dry land crop production in the semiarid U.S. Great Plains is decreas- ing (Bouman et al., 1995; Wicks et al., 1995). There has been little concern about the need to counteract the acidification with lime application because many of the agricultural soils in this area are derived from 
calcareous parent materials and receive limited precipitation.

The three-year rotation of winter wheat-sorghum/ corn-fallow (W-S/C-F) has become a common dry land production system in the semiarid central U.S. Great Plains. For example, in some counties in Nebraska and Kansas, the W-S/C-F rotation occupies up to $90 \%$ of the non-irrigated crop area (Wicks et al., 1995). This system depends on herbicide application to winter wheat stubble after wheat harvest to keep the field weed free to conserve soil moisture for grain sorghum or corn that is planted the following spring (Wicks et al., 1995).

Several studies have found that the soil $\mathrm{pH}$ in the $\mathrm{W}-\mathrm{S} / \mathrm{C}-\mathrm{F}$ rotation is decreasing over time (Wicks et al., 1988; Bowman and Halverson, 1998). Wicks et al. (1988) reported that after 16 years of cropping, the soil $\mathrm{pH}$ (surface $15 \mathrm{~cm}$ ) decreased from 7.2 to 5.8 and 5.3 for conventional tillage (CT) and no till (NT), respectively. The acidification was attributed to the application of ammonium-based fertilizers. Ammonium nitrate (AN) was applied at an annual rate of $45 \mathrm{~kg}$ $\mathrm{ha}^{-1}$ from 1962 to 1965 and $67 \mathrm{~kg} \mathrm{ha}^{-1}$ from 1966 to 1979. After a nine-year study conducted by Bowman and Halverson (1998), the soil $\mathrm{pH}$ values under a WS/C-F rotation in Nebraska were 6.3, 6.2, 5.8, 5.4, and 5.0 in the surface $5 \mathrm{~cm}$ after the application of 0 , $28,56,84$, and $112 \mathrm{~kg} \mathrm{~N} \mathrm{ha}^{-1}$ as either AN or anhydrous $\mathrm{NH}_{3}$, respectively.

Acidification is accelerated in crop production as a result of nitrification of ammonium-based fertilizers and leaching of the resulting $\mathrm{NO}_{3}{ }^{-}$, and removal of bases from the soil in the harvested plant or grain. (Barak et al., 1997; Bouman et al., 1995; Dick, 1983; Heenan and Taylor, 1995; Juo et al., 1995; Lilienfein et al., 2000). Often, tillage practices will result in differences in soil acidification rate. Many studies show that the surface soil $\mathrm{pH}$ is often lower under NT compared to CT practices (Wicks et al., 1988; Lilenfein et al., 2000; Mahler and Harder, 1984; Bouman et al., 1995). In the W-S/C-F rotation most producers use NT practices. However, there are some producers who use some degree of tillage to control weeds during the fallow period. There is a need for research to assess the differences and causes of acidification between different tillage practices.
Soil acidification is generally more pronounced in areas of higher rainfall and on soils with low buffer capacities (Poss et al., 1995). However, soil acidification can occur over longer periods of time in arid climates. Ranges of acidification rates have been reported from near 0 to $20 \mathrm{kmoles} \mathrm{H}^{+} \mathrm{ha}^{-1} \mathrm{yr}^{-1}$ in research located in a variety of climates and cropping systems (Poss et al., 1995). In a study conducted by Poss et al. (1995), the calculated acidification rate of a wheat cropping system in semiarid Australia was

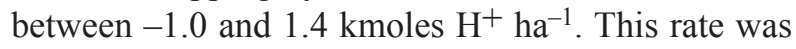
measured in the top $25 \mathrm{~cm}$ of soil, which received annual applications of $157 \mathrm{~kg} \mathrm{~N} \mathrm{ha}^{-1}$ as diammonium phosphate and urea. This low acidification rate was attributed to small losses of $\mathrm{NO}_{3}{ }^{-}$below the root zone.

The acidification of soils over time can result in decreased plant growth and yields when soil $\mathrm{pH}$ falls below critical thresholds that lead to increased activity of $\mathrm{Al}$ and $\mathrm{Mn}$. The application of liming materials may eventually be needed to increase $\mathrm{pH}$ in these soils. The amount and timing of the lime applications will depend on the rate of acidification.

There is little information on the long-term effects of NT practices on the acidification rate of soil under the $\mathrm{W}-\mathrm{S} / \mathrm{C}-\mathrm{F}$ rotation receiving annual applications of ammonium-based fertilizers. The objectives of this study were to: (1) determine the acidification rates of soil under long-term NT [NT(LT)] and soil that has been converted from CT to NT $[\mathrm{NT}(\mathrm{C})]$, (2) assess the causes of soil acidification by determining the components of a proton budget for both NT treatments at the $0-30 \mathrm{~cm}$ depth, and (3) determine the lime applications needed to counteract the acidification.

\section{Materials and methods}

\section{Experimental site}

This study was conducted on a Holdrege silt loam soil (fine-silty, mixed, mesic Typic Argiustolls) at the University of Nebraska West Central Research and Extension Center, North Platte, NE (longitude=96.02; latitude $=41.37$; Elevation $=861 \mathrm{~m}$ above sea level). 
In 1962 a study was established on the site to assess various weed control strategies in the $\mathrm{W}-\mathrm{S} / \mathrm{C}-\mathrm{F}$ rotation (Wicks et al., 1988). The study site consists of three adjacent strips, and each strip was either fallow or planted to one of the other three crops of the $\mathrm{W}$ $\mathrm{S} / \mathrm{C}-\mathrm{F}$ rotation. With this arrangement, all three components of the $\mathrm{W}-\mathrm{S} / \mathrm{C}-\mathrm{F}$ rotation were included all years. The "-S/C-" component of the crop rotation was grain sorghum from 1962 to 1992, and corn from 1993 to 2003. Each strip had five weed management strategy treatments and five replications arranged in a Latin Square design. Two of the weed management strategies used included NT and conventional tillage (CT). The NT [NT(LT)] treatment used herbicides as the primary weed management strategy and had not been tilled since 1962. The CT treatment used sweep plowing to a depth of approximately $5 \mathrm{~cm}$ twice after wheat harvest and disking to a depth of approximately $10 \mathrm{~cm}$ once in the spring. No herbicides were used in the CT treatment. The CT was maintained from 1962 to 1989 . In 1989 the CT treatment was converted to NT (NT(C)). The NT(LT) weed management treatment continued from 1989 to 2003 for both the NT(LT) and NT(C) treatments. This study focused on the NT(LT) and NT(C) treatments from 1989 to 2003.

\section{Crop management}

Nitrogen fertilizer was applied before planting winter wheat, sorghum, or corn as ammonium nitrate (AN) and urea ammonium nitrate (UAN). Ammonium nitrate was applied at a rate of $23 \mathrm{~kg} \mathrm{~N} \mathrm{ha}^{-1}$ in 1989. A total of $650 \mathrm{~kg} \mathrm{~N} \mathrm{ha}^{-1}$ was applied as UAN from 1990 to $2003\left(50 \mathrm{~kg} \mathrm{~N} \mathrm{ha}^{-1} \mathrm{yr}^{-1}\right)$. Both NT treatments received the same yearly $\mathrm{N}$ application rates. Fertilizer application rates were based on typical rates adopted by producers using the W-S/C-F system. Grain was harvested for each crop and removed from the field during the 15 year period. Crop residues remained in the field. Crop yields are presented in Tarkalson et al. (2005).

\section{Soil sampling and analysis}

Soil samples were taken at depth increments of $0-5$, $5-10,10-15$, and $15-30 \mathrm{~cm}$ in the spring of 1989 and 2003 from all five replications of the two NT treat- ments in the three crop-year strips. Soil samples used for chemical analysis were air-dried and ground to pass through a 2-mm sieve prior to laboratory analysis. The soil samples were analyzed for $\mathrm{pH}(1: 1$, soil: water) and organic matter (OM) (Nelson and Sommers, 1982) in 2003. Bulk densities for each sampling depth interval were determined from vertical soil samples obtained from a soil core sampler with a known volume. Data were averaged over the three strips for each sampling depth and NT treatment. For a detailed discussion on the long-term effect of tillage practices on the soil chemical properties of this soil see Tarkalson et al. (2005).

\section{Acidification rates}

The acidification rate from 1989 to 2003 for both NT treatments was determined for depth increments of $0-5,5-10,10-15$, and $15-30 \mathrm{~cm}$ and for the entire sampling depth. The acidification rate is defined as the rate of acid addition that needs to be neutralized in order to maintain a constant $\mathrm{pH}$ (Helyar and Porter, 1989):

$$
\mathrm{AR}=\Delta \mathrm{pH} \times \mathrm{pHBC} \times \mathrm{BD} \times \mathrm{Vol}) / 1000
$$

where, $\mathrm{AR}=$ acidification rate $\left(\mathrm{kmol} \mathrm{H} \mathrm{H}^{+} \mathrm{ha}^{-1}\right.$ time period $\left.^{-1}\right), \Delta \mathrm{pH}=$ change in $\mathrm{pH}$ over the time period ( $\mathrm{pH}$ unit), $\mathrm{pHBC}=\mathrm{pH}$ buffer capacity of the soil at the end of the time period $\left(\mathrm{mol} \mathrm{H} \mathrm{H}^{+} \mathrm{kg}^{-1} \mathrm{pH}\right.$ unit $\left.{ }^{-1}\right)$, $\mathrm{BD}=$ bulk density of the soil $\left(\mathrm{kg} \mathrm{m}^{-3}\right), \mathrm{Vol}=$ volume of soil per unit area $\left(\mathrm{m}^{3} \mathrm{ha}^{-1}\right)$.

To determine the $\mathrm{pH}$ buffer capacity of the tillage treatments and to check for variability in the $\mathrm{pH}$ buffer capacity across the research area, the buffer capacities were determined at each depth for two replications from soil samples collected in 2003. The $\mathrm{pH}$ buffer capacities were determined by titrating $50 \mathrm{~g}$ of each soil sample in sealable polyethylene bags with $\mathrm{H}_{2} \mathrm{SO}_{4}$ and $\mathrm{CaCO}_{3}$ at rates of $0,2,4,8,16$, and 32 cmol $\left(\mathrm{H}^{+}\right.$or $\left.1 / 2 \mathrm{CO}_{3}^{-2}\right) \mathrm{kg}^{-1}$ (Magdoff and Bartlett, 1985). The rates of $\mathrm{CaCO}_{3}$ were added to the soils as a suspension in distilled water. After amendments were added, they were mixed with the soil. Distilled water was added to each soil/amendment mixture to reach approximately field capacity. The bags were sealed and stored at room temperature for 1 month. The soils were then air-dried and ground for deter- 
mination of $\mathrm{pH}$ (1:1, soil:water). Regression analysis was used to determine the buffer capacities within the linear range of the titration curve (approximately between $\mathrm{pH} 4$ and 7):

$$
\mathrm{pHBC}=[(5-b) / m]-(6-b) / m
$$

where, $\mathrm{pHBC}=\mathrm{pH}$ buffer capacity of the soil at the end of the time period $\left(\mathrm{cmol} \mathrm{H}^{+} \mathrm{kg}^{-1} \mathrm{pH}\right.$ unit $\left.{ }^{-1}\right), 5$ and $6=$ one unit $\mathrm{pH}$ range used in calculation, $b=$ intercept, $m=$ slope.

\section{Proton budgets}

To determine the sources of acidification in the soil, proton budgets were developed for the NT(LT) and NT(C) treatments in the $0-30 \mathrm{~cm}$ soil depth based on the approach outlined by Helyar and Porter (1989). Components of the proton budget were determined for each sampling depth and summed to give a total for the 0-30 cm depth. The approach outlined by Helyar and Porter (1989) determines the inputs and outputs of protons $\left(\mathrm{H}^{+}\right)$to and from the soil. Protons are either added or removed from the soil, or produced or consumed in reactions in the soil (Poss et al., 1995). The acid addition (AA), which is equivalent to the acidification rate (AR in equation 1 ) can be determined by taking into account the major components influencing the inputs and outputs of protons ( $\mathrm{N}$ cycle, $\mathrm{C}$ cycle, $\mathrm{Al}$ cycle, $\mathrm{Mn}$ cycle, acid additions, and other alkali additions). The acid addition to a soil can be calculated as:

$$
\begin{aligned}
& \mathrm{AA}=\mathrm{N}_{b}+\mathrm{OA}_{b}+\mathrm{HCO}_{3 b}+\mathrm{Al}_{b}+\mathrm{Mn}_{b}+\mathrm{L}_{b} \\
& +\mathrm{H}_{b} \\
& \mathrm{~N}_{b}=\left(\mathrm{NH}_{4 \mathrm{ad}}^{+}-\mathrm{NO}_{3 \mathrm{ad}}^{-}-\mathrm{NH}_{4 \mathrm{ac}}^{+}+\mathrm{NO}_{3 \mathrm{ac}}^{-}+\mathrm{NO}_{3 \mathrm{ex}}^{-}\right. \\
& \left.-\mathrm{NH}_{4 \mathrm{ex}}^{+}\right) \\
& \mathrm{OA}_{b}=\left(\mathrm{OA}_{\mathrm{ac}}+\mathrm{OA}_{\mathrm{ex}}-\mathrm{OA}_{\mathrm{ad}}\right) \\
& \mathrm{HCO}_{3 \mathrm{~b}}=\left(\mathrm{HCO}_{3 \mathrm{ac}}^{-}+\mathrm{HCO}_{3 \mathrm{ex}}^{-}-\mathrm{HCO}_{3 \mathrm{ad}}^{-}\right) \\
& \mathrm{Al}_{b}=\left(-\mathrm{Al}_{\mathrm{ac}}^{+3}-\mathrm{Al}_{\mathrm{ex}}^{+3}\right)
\end{aligned}
$$

$$
\begin{aligned}
& \mathrm{Mn}_{b}=\left(\mathrm{Mn}_{\mathrm{ac}}^{+2}-\mathrm{Mn}_{\mathrm{ex}}^{+2}\right) \\
& \mathrm{L}_{b}=\left(-\mathrm{L}_{\mathrm{ad}}\right) \\
& \mathrm{H}_{b}=\left(\mathrm{H}_{\mathrm{ad}}^{+}-\mathrm{H}_{\mathrm{ex}}^{+}\right)
\end{aligned}
$$

where, $\mathrm{AA}=$ acid addition , and $\mathrm{N}_{b}, \mathrm{OA}_{b}, \mathrm{HCO}_{3 b}$, $\mathrm{Al}_{b}, \mathrm{Mn}_{b}, \mathrm{~L}_{b}, \mathrm{H}_{b}$, are the proton budgets for the nitrogen, organic anions (OA), $\mathrm{HCO}_{3}{ }^{-}, \mathrm{Al}^{+3}, \mathrm{Mn}^{+2}, \mathrm{~L}$ (alkaline inorganic compounds (lime)), and $\mathrm{H}^{+}$(acids) components, respectively. The subscripts "ad," "ac," and "ex" represent additions, accumulation, and export, respectively. The AA and all other components are in units of $\mathrm{kmol} \mathrm{ha}^{-1}$ time period ${ }^{-1}$.

To reduce the amount and difficulty of the analysis needed to be conducted, components that were believed to have a negligible effect on acidification of the soil in this study were not included. There were no lime additions to the soil during the 15 -year period; therefore the $\mathrm{L}_{b}$ component was ignored. The $\mathrm{Al}_{b}$ and $\mathrm{Mn}_{b}$ components were also ignored since the effects of $\mathrm{Al}$ and $\mathrm{Mn}$ cycle reactions are important in soils under anaerobic conditions, such as in paddy rice production, and usually only influence soil acidification over long periods of time (periods of soil formation) in well-drained soils (Barak et al., 1997; Helyar and Porter, 1989). Iron transformations and the sulfur cycle can also affect soil $\mathrm{pH}$, although their effects are usually considered small compared to other components ( $\mathrm{N}$ cycle), especially in well-drained soils, and consequently were not included in the proton budget (Barak et al., 1997; Helyar and Porter, 1989). The AA equation (equation 3) was simplified to:

$$
\mathrm{AA}=\mathrm{N}_{b}+\mathrm{OA}_{b}+\mathrm{HCO}_{3 b}+\mathrm{H}_{b}
$$

Figure 1 shows the effect of addition, accumulation, and export of $\mathrm{NH}_{4}^{+}$and $\mathrm{NO}_{3}^{-}$from the soil in relation to several $\mathrm{N}$ reference states on soil acidification and alkalinization. Additions of $\mathrm{NH}_{4}^{+}$to soil causes acidity because plants release $\mathrm{H}^{+}$when $\mathrm{NH}_{4}^{+}$is assimilated to maintain the charge balance at the soil/ root interface, $\mathrm{H}^{+}$is a product of nitrification and conversion to $\mathrm{NH}_{3}$. Additions of $\mathrm{NO}_{3}{ }^{-}$causes alkalinity due to the consumption of $\mathrm{H}^{+}$during the con- 


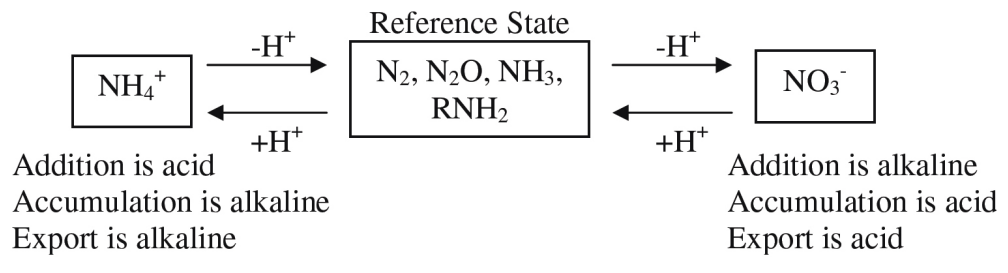

Figure 1. Input and output of $\mathrm{H}^{+}$from nitrogen cycling in soil. The terms $) \mathrm{H}^{+}$and $+\mathrm{H}^{+}$represent increased $\mathrm{H}^{+}$and decreased $\mathrm{H}^{+}$, respectively (adapted from Poss et al., 1995).

version of $\mathrm{NO}_{3}{ }^{-}$to organic $\mathrm{N}\left(\mathrm{R}-\mathrm{NH}_{3}\right)$ in the plant and during denitrification, and by the production of $\mathrm{OH}^{-}$as $\mathrm{NO}_{3}^{-}$is assimilated (Avila-Segura et al., 2000; Barak et al., 1997; Fan et al., 2002; Tang et al., 2000). The major inputs of $\mathrm{NH}_{4}^{+}$and $\mathrm{NO}_{3}{ }^{-}$to the soil was from AN and UAN fertilizer. The urea component of UAN does not directly contribute to the additions of $\mathrm{NH}_{4}^{+}$and $\mathrm{NO}_{3}{ }^{-}$. The hydrolysis of urea, nitrification of the resulting $\mathrm{NH}_{4}{ }^{+}$, and utilization of the resulting $\mathrm{NO}_{3}{ }^{-}$is considered acid/base neutral (Poss et al., 1995). The acidifying effect of $\mathrm{NH}_{4}^{+}$and the alkaline effect of $\mathrm{NO}_{3}{ }^{-}$from additions to the soil system and production from urea balance each other if all the $\mathrm{NO}_{3}{ }^{-}$applied in and formed from fertilizer is utilized by plants and converted back to into the original input forms (Bolan et al., 1991):

$$
\begin{aligned}
& \mathrm{CO}\left(\mathrm{NH}_{2}\right)_{2}+4 \mathrm{O}_{2} \rightarrow 2 \mathrm{H}^{+}+2 \mathrm{NO}_{3}^{-}+\mathrm{H}_{2} \mathrm{O}+\mathrm{CO}_{2} \\
& \mathrm{NH}_{4} \mathrm{NO}_{3}+2 \mathrm{O}_{2} \rightarrow 2 \mathrm{H}^{+}+2 \mathrm{NO}_{3}^{-}+\mathrm{H}_{2} \mathrm{O} \\
& \mathrm{R}-\mathrm{OH}+\mathrm{NO}_{3}^{-}+\mathrm{H}^{+} \rightarrow \mathrm{R}-\mathrm{NH}_{2}+2 \mathrm{O}_{2}
\end{aligned}
$$

The net reactions of ammoniacal fertilizers in soils and associated uptake and assimilation of nitrate by plants is acid/base neutral (Barak et al., 1997):

$$
\begin{gathered}
{\left[\mathrm{NH}_{4} \mathrm{NO}_{3}, 2 \mathrm{NH}_{3}, \mathrm{CO}\left(\mathrm{NH}_{2}\right)_{2}+2 \mathrm{R}-\mathrm{OH}\right.} \\
\rightarrow 2 \mathrm{R}-\mathrm{NH}_{2}+\mathrm{H}_{2} \mathrm{O}\left(+\mathrm{O}_{2}\right)\left(+\mathrm{CO}_{2}\right)
\end{gathered}
$$

Based on this net reaction, soil acidification is not directly caused by input of ammoniacal fertilizers but rather by ammoniacal $\mathrm{N}$ inputs greater than the amount assimilated by the crop and net export of or- ganic ions in plant material (e.g. grain harvest and removal) (Barak et al., 1997). Like all theoretical models, the proton budget model used in this study has limitations. The reactions influencing proton production and consumption are separated both spatially and temporally in the soil, which is not taken into account when creating the proton budget.

Accumulation of $\mathrm{NH}_{4}^{+}$causes alkalinity over time by reducing $\mathrm{H}^{+}$in the soil. Accumulation of $\mathrm{NO}_{3}^{-}$causes acidity over time as $\mathrm{H}^{+}$is released during nitrification. The export of $\mathrm{NO}_{3}^{-}$causes acidity because the loss of $\mathrm{NO}_{3}{ }^{-}$reduces the amount of $\mathrm{H}^{+}$ consumed as $\mathrm{NO}_{3}{ }^{-}$is reduced in the plant, and reduces that amount of alkalinity produced as $\mathrm{NO}_{3}{ }^{-}$is assimilated by the plant. The export of $\mathrm{NH}_{4}{ }^{+}$causes alkalinity by removing a source of $\mathrm{H}^{+}$both from plant root release when $\mathrm{NH}_{4}{ }^{+}$is assimilated and from nitrification. The main pathway for the export of $\mathrm{NH}_{4}^{+}$ and $\mathrm{NO}_{3}{ }^{-}$is leaching.

The accumulation of OA causes acidity by the release of $\mathrm{H}^{+}$into the soil. The $\mathrm{OA}_{\mathrm{ac}}$ is determined using the equation proposed by Helyar and Porter (1989). The final OA content and the undissociated weak acids at the initial $\mathrm{pH}$ make up the $\mathrm{OA}_{\mathrm{ac}}$ :

$$
\begin{aligned}
\mathrm{OA}_{\mathrm{ac}}= & \mathrm{BD} \times \mathrm{V} \times \mathrm{K} \times\left[\mathrm{OM}_{t 2}\left(\mathrm{pH}_{t 1}-1.5\right)\right] \\
& -\left[\mathrm{OM}_{t 1}\left(\mathrm{pH}_{t 1}-1.5\right)\right]
\end{aligned}
$$

where, $\mathrm{BD}=$ bulk density $\left(\mathrm{g} \mathrm{cm}^{-3}\right), \mathrm{V}=$ soil volume $\left(\mathrm{m}^{3}\right), \mathrm{OM}=$ fraction of organic matter in soil (unitless), $\mathrm{K}=$ average slope coefficient for soil organic $\left(\mathrm{mol}(+) \mathrm{kg}^{-1}\right)$, and $\mathrm{OA}_{\mathrm{ac}}$ is in units of $\mathrm{kmol}(+) \mathrm{ha}^{-1}$. A value of $\mathrm{K}=0.32 \mathrm{~mol}(+) \mathrm{kg}^{-1}$ was used in this study (Helling et al., 1964). The subscripts $t 1$ and $t 2$ represent values in 1989 and 2003, respectively. Values used in the calculation are presented in Table 1. 
Table 1. Change in $\mathrm{pH}$ from 1989 to 2003, bulk density (BD) of the soils collected in 2003, pH of the soils collected in 1989 $\left(\mathrm{pH}_{t 1}\right)$ and $2003\left(\mathrm{pH}_{t 2}\right)$, and values of organic matter of the soils collected in $1989\left(\mathrm{OM}_{t 1}\right)$ and $2003\left(\mathrm{OM}_{t 2}\right)$ used to calculate accumulation of $\mathrm{OA}\left(\mathrm{OA}_{\mathrm{ac}}\right.$, Equation 12).

\begin{tabular}{llcclll}
\hline \multicolumn{2}{c}{ Sample depth $(\mathrm{cm})$} & $\mathrm{pH}$ Change (1989-2003) & $\mathrm{BD}\left(\mathrm{g} \mathrm{cm}^{-3}\right)$ & $\mathrm{pH}_{t 1}$ & $\mathrm{OM}_{t 1}{ }^{\mathrm{a}}$ & $\mathrm{OM}_{t 2}{ }^{\mathrm{a}}$ \\
\hline $\mathrm{NT}(\mathrm{LT})$ & $0-5$ & +0.1 & 0.841 & 5.1 & 0.019 & 0.018 \\
& $5-10$ & -0.5 & 0.852 & 5.9 & 0.013 & 0.013 \\
& $10-15$ & -0.6 & 0.850 & 6.5 & 0.013 & 0.013 \\
& $15-30$ & -0.2 & 0.941 & 6.8 & 0.010 & 0.010 \\
$\mathrm{NT}(\mathrm{C})$ & -0.3 & 0.871 & 6.1 & 0.014 & 0.014 \\
& Ave. & -0.4 & 0.856 & 5.6 & 0.018 & 0.018 \\
& $5-10$ & -0.3 & 0.856 & 5.7 & 0.015 & 0.013 \\
& $10-15$ & -0.3 & 0.851 & 6.3 & 0.014 & 0.013 \\
& $15-30$ & -0.3 & 0.941 & 6.9 & 0.010 & 0.010 \\
& Ave. & -0.325 & 0.876 & 6.1 & 0.014 & 0.014 \\
\hline
\end{tabular}

${ }^{a}$ Listed as a fraction $(\% \mathrm{OM} / 100)$.

The export of OA causes acidity because it is a sink for removing $\mathrm{H}^{+}$, and the addition of OA causes alkalinity by reducing the $\mathrm{H}^{+}$pool. Organic anions are exported from this system in harvested grain and are added to the system in crop residues. Both $\mathrm{OA}_{\mathrm{ex}}$ and $\mathrm{OA}_{\mathrm{ad}}$ were calculated using published average ash alkalinity values for wheat, sorghum, and corn grain and residues (Pierre and Banwart, 1973). Grain ash alkalinity values of 5, 6, and $6 \mathrm{cmol}(+)$ $\mathrm{kg}^{-1}$ and residue ash alkalinity values of 33, 32, and $25 \mathrm{cmol}(+) \mathrm{kg}^{-1}$ were used for wheat, sorghum, and corn, respectively. Grain yields over the 15 years are reported in Tarkalson et al. (2005). The quantity of residue added to the soil over the 15 years was estimated using average values of $1.72,1.25$, and 1.07 $\mathrm{kg}$ residue $\mathrm{kg}_{\text {grain }^{-1}}$ for wheat, sorghum, and corn, respectively (McCarthy et al., 1993).

The addition of $\mathrm{HCO}_{3}{ }^{-}$causes alkalinity because it is a sink for $\mathrm{H}^{+}$. The accumulation of $\mathrm{HCO}_{3}^{-}$ causes acidity because an increase in the anion is a result of $\mathrm{H}^{+}$being released from carbonic acid, which forms from the reaction of $\mathrm{CO}_{2}$ with water. The export of $\mathrm{HCO}_{3}{ }^{-}$causes acidity because it is a sink for removing $\mathrm{H}^{+}$. The impact of fluxes of $\mathrm{HCO}_{3}{ }^{-}$on soil acidity were estimated from the amount and $\mathrm{pH}$ of precipitation, the estimated $\mathrm{pH}$ of the soil water, the partial pressure of $\mathrm{CO}_{2}$ in which the water from precipitation is equilibrated, and the proportion of precipitation leaching below $30 \mathrm{~cm}$
(Helyar and Porter, 1989). Relationships derived from Lindsay (1979) were used to calculate the additions and export of $\mathrm{HCO}_{3}$ as:

$$
\begin{aligned}
& \mathrm{HCO}_{3}^{-}{ }_{\mathrm{ad}}=\left[10^{-(-\log 0.0003-\mathrm{pHp}+7.82)}\right] \times V_{\mathrm{p}} / 1000 \\
& \mathrm{HCO}_{3}^{-}{ }_{\text {ex }}^{-}=\left[10^{-(-\log 0.003-\mathrm{pHsw}+7.82)}\right] \times V_{\mathrm{L}} / 1000
\end{aligned}
$$

where, $\mathrm{pHp}=\mathrm{pH}$ of precipitation, $\mathrm{pHsw}=\mathrm{pH}$ of soil water at a depth of $30 \mathrm{~cm}, V_{\mathrm{p}}=$ volume of precipitation (L), $V_{\mathrm{L}}=$ volume of soil water leached below 30 $\mathrm{cm}(\mathrm{L})$, and the 0.0003 and 0.003 constants are the partial pressures (atm.) of atmospheric and soil air $\mathrm{CO}_{2}$, respectively. $\mathrm{HCO}_{3}{ }^{-}$ad and $\mathrm{HCO}_{3}{ }^{-}$ex are in units of $\mathrm{kmol}(+) \mathrm{ha}^{-1}$.

The proportion of precipitation leaching below the $30-\mathrm{cm}$ depth was calculated daily over a 15 year period (1989-2003) using a computer model (J.O. Payero, 2005, personal communication). The model used the dual crop coefficient method described by Wright (1982) and Allen et al. (1998) to calculate crop water use. The model calculated the daily soil water balance for 30-cm soil depth based on weather, crop, and soil information. Weather data (rainfall and all the variables needed to calculate reference evapotranspiration, such as solar radiation, relative humidity, air temperature, and wind speed) were obtained from an automatic weather station located near the 
study site. The proportion of water moving below the $30 \mathrm{~cm}$ depth was calculated by dividing the total volume of soil water moving below the $30 \mathrm{~cm}$ depth by the total precipitation over the 15 years. The assumption was made that there was no runoff from the plots. This assumption was made due to the site having slopes of less than $1 \%$ and high infiltration rates due to the no-till management on the plots.

The addition and export of $\mathrm{H}^{+}$from the soil was calculated from the amount and $\mathrm{pH}$ of precipitation, the $\mathrm{pH}$ of the soil water, and the proportion of precipitation leaching below $30 \mathrm{~cm}$ (Helyar and Porter, 1989):

$$
\begin{aligned}
& \mathrm{H}_{\mathrm{ad}}^{+}=\left(\left(10^{-\mathrm{pHp}}-10^{-\mathrm{pOHp}}\right) \times V_{\mathrm{p}}\right) / 1000 \\
& \mathrm{H}_{\mathrm{ex}}^{+}=\left(\left(10^{-\mathrm{pHsw}}-10^{-\mathrm{pOHsw}}\right) \times V_{\mathrm{L}}\right) / 1000
\end{aligned}
$$

where, $\mathrm{pHp}=\mathrm{pH}$ of precipitation, $\mathrm{pHsw}=\mathrm{pH}$ of soil water at a depth of $30 \mathrm{~cm}, \mathrm{pOHp}=\mathrm{pOH}$ of precipitation, $\mathrm{pOHsw}=\mathrm{pOH}$ of soil water at a depth of $30 \mathrm{~cm}$, $V_{\mathrm{p}}=$ volume of precipitation $(\mathrm{L})$, and $V_{\mathrm{L}}=$ volume of soil water leached below $30 \mathrm{~cm}(\mathrm{~L})$. Both $\mathrm{H}^{+}{ }_{\text {ad }}$ and $\mathrm{H}^{+}$ex are in units of $\mathrm{kmol}(+) \mathrm{ha}^{-1}$.

\section{Data analysis}

Buffer capacities were determined for both NT treatments at depths of $0-5$ and $5-10 \mathrm{~cm}$. For depths of $10-15$ and $15-30 \mathrm{~cm}$ the soils from the two NT treatments were combined because past literature showed that buffer capacities for deeper depths remained fairly constant for a given soil and there were no differences in $\mathrm{pH}$ between the tillage treatments in 2003 at these depths (Tarkalson et al., 2005). Regression analysis was used to determine the buffer capacities within the linear range of the titration curve (approximately between $\mathrm{pH} 4$ and 7). Analysis of variance was used to test NT treatment and soil depth main effects and interactions for soil acidification. Least significant difference (LSD) was used to determine the differences between tillage and depth treatment means. All statistical analysis procedures were conducted using Statistix 8 (Analytical Software, 2002). Significance was determined for all analysis at the 0.05 probability level.

\section{Results and discussion}

\section{Titration curves}

The titration curves for NT(LT) at $0-5$ and 5-10 $\mathrm{cm}, \mathrm{NT}(\mathrm{C})$ at $0-5$ and $10-15 \mathrm{~cm}$, combined NT(LT) and $\mathrm{NT}(\mathrm{C})$ at $10-15$ and $15-30 \mathrm{~cm}$ are shown in Figure 2. The soils for both NT treatments at all depths were highly buffered below $\mathrm{pH} 4$ and above $\mathrm{pH}$ 7. In the highly buffered ranges, association and dissociation reactions of $\mathrm{H}^{+}$dominated over dissolution and precipitation reactions (Helyar and Porter, 1989). There were little differences in the curves between treatments at the same depth. The titration curves shifted up and to the left as the soil depth increased (Figures 2 and 3). The differences in the curves are most likely a result of differences in the soils initial pH. Tarkalson et al. (2005) showed that soil $\mathrm{pH}$ increased with depth for both the NT(LT) and NT(C) treatments at this site. The $\mathrm{pH}$ in the $0-5$ $\mathrm{cm}$ depth was lower for NT(LT) compared to NT(C) but at the $5-10 \mathrm{~cm}$ depth the NT(C) treatment was higher than NT(LT) treatment. There were no significant differences in soil $\mathrm{pH}$ at depths of 10-15 and $15-30 \mathrm{~cm}$.

\section{Buffer capacity determinations}

The relationships between the $\mathrm{CaCO}_{3}$ and $\mathrm{H}_{2} \mathrm{SO}_{4}$ amendment rates and soil $\mathrm{pH}$ for NT(LT) at $0-5$ and 5-10 cm, NT(C) at 0-5 and 10-15 cm, and combined NT(LT) and NT(C) at 10-15 and 15-30 cm were all significant and had high linear regression correlation coefficients (Figure 3, Table 2). The buffer capacities ranged from 2.02 to $2.97 \mathrm{cmol}^{+}+\mathrm{kg}^{-1} \mathrm{pH}$ unit ${ }^{1}$ with a depth weighted average of $2.21 \mathrm{cmol}(+) \mathrm{kg}^{-1}$ $\mathrm{pH}$ unit $^{-1}$ over all titration curves. For both NT treatments the buffer capacities were greatest in the $0-5$ and 5-10 cm depths and decreased at deeper depths (Table 1). This is likely a result of decreasing OM content with depth (Tarkalson et al., 2005) (Table 1). Other research has demonstrated the increase in soil $\mathrm{pH}$ buffer capacity with increasing OM (Helyar et al., 1990). 


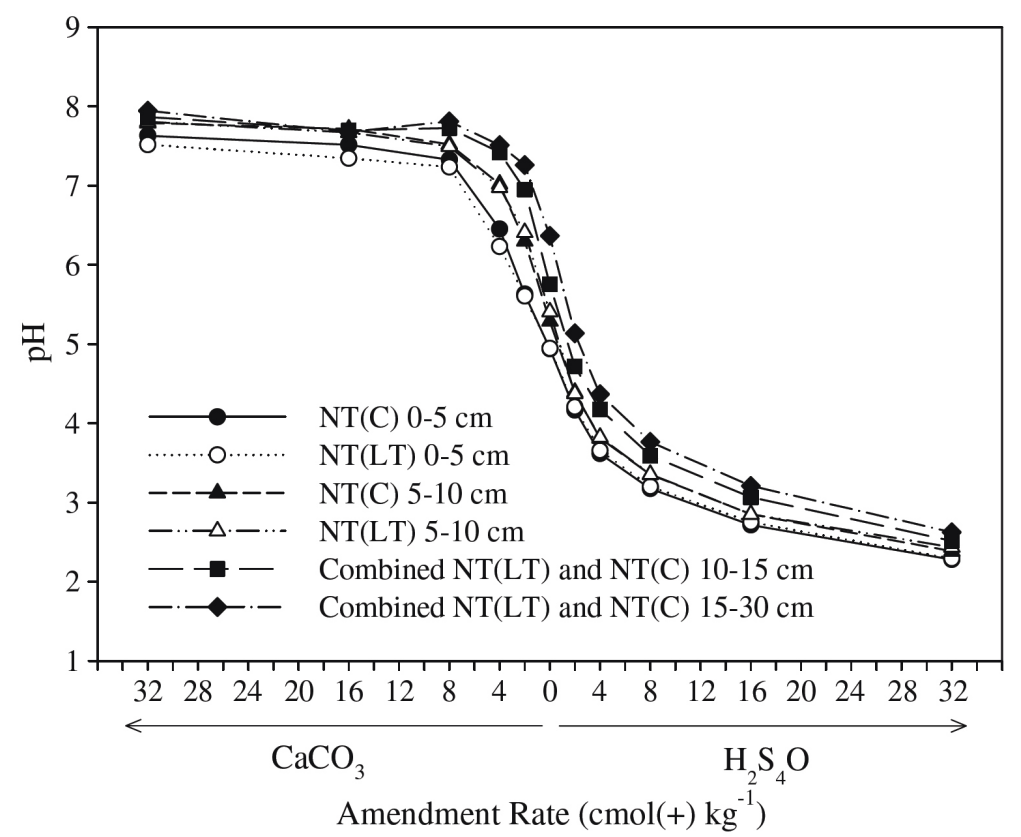

Figure 2. Titration curves of no-till (NT) treatments for soil depths of $0-5,5-10,10-15$, and $15-30 \mathrm{~cm}$.

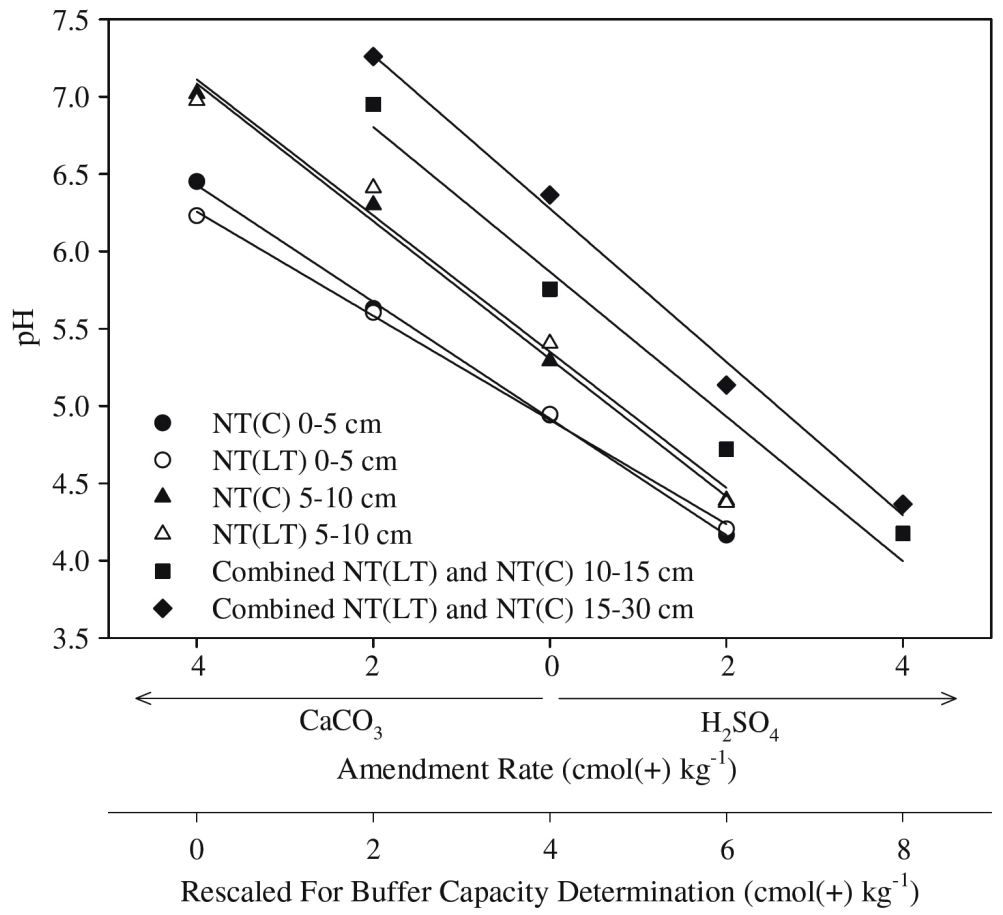

Figure 3. Regression of linear range of titration curves for the no-till (NT) treatments at soil depths of $0-5,5-10,10-15$, and $15-$ $30 \mathrm{~cm}$. 
Table 2. Regression equations and correlation coefficients of linear portion of $\mathrm{pH}$ buffer capacity curves (Figures 2 and 3). Based on the rescaled $\mathrm{x}$ axis in Figure 3.

\begin{tabular}{llcccc}
\hline Tillage Treatment & $\begin{array}{l}\text { Depth } \\
(\mathrm{cm})\end{array}$ & $r^{2}$ & $\begin{array}{c}\text { Intercept } \\
(b)\end{array}$ & $\begin{array}{c}\text { Slope } \\
(m)\end{array}$ & $\begin{array}{c}\text { Soil pH Buffer Capacity } \\
\left(\mathrm{cmol}^{\mathrm{a}}(+) \mathrm{kg}^{-1} \mathrm{pH} \mathrm{unit}^{-1}\right)\end{array}$ \\
\hline NT(LT) & $0-5$ & $1.0^{* *}$ & 6.26 & -0.34 & 2.65 \\
& $5-10$ & $0.999^{* *}$ & 7.11 & -0.44 & 2.25 \\
NT(C) & $0-5$ & $0.999^{* *}$ & 6.43 & -0.38 & 2.97 \\
& $5-10$ & $0.999^{* *}$ & 7.09 & -0.45 & 2.27 \\
Combined NT(LT) and NT(C) & $10-15$ & $0.999^{* *}$ & 6.80 & -0.47 & 2.14 \\
& $15-30$ & $0.999^{* *}$ & 7.27 & -0.50 & 2.02 \\
\hline
\end{tabular}

**Significant at the 0.01 probability level.

${ }^{a}$ Based on Equation 2.

\section{Acidification rates}

There were significant differences in acidification rates between depths when averaged over both NT treatments but there were no differences between the NT treatments when averaged over depth (Table 3). For the NT(LT) treatment there was very little change in $\mathrm{pH}$ in the $0-5 \mathrm{~cm}$ depth (Table 1 ). The $\mathrm{pH}$ did decrease in the 5-30 cm depths. The $\mathrm{pH}$ decreased about the same at all soil depths for the NT(C) treatment (Table 1). The average annual acidification rate over the $30 \mathrm{~cm}$ sampling depth was $1.13 \mathrm{kmol} \mathrm{H}^{+} \mathrm{ha}^{-}$ ${ }^{1} \mathrm{yr}^{-1}$ for the NT(LT) treatment and $1.48 \mathrm{kmol} \mathrm{H}^{+} \mathrm{ha}^{-}$ ${ }^{1} \mathrm{yr}^{-1}$ for the NT(C) treatment (Table 3). Based on the calculated acidification rates, 57 and $74 \mathrm{~kg} \mathrm{CaCO}_{3}$ $\mathrm{ha}^{-1} \mathrm{yr}^{-1}$ are needed to balance the acidification in the NT(LT) and NT(C) treatments, respectively.

There was a significant tillage by depth interaction. The LSD mean separation for the acidification rates shows the differences in tillage over depth. The annual acidification rate is greater in the surface 5 $\mathrm{cm}$ for the NT(C) treatment compared to the NT(LT) treatment (Table 3). The NT(LT) treatment had a lower initial pH in 1989 (5.1) compared to the NT(C) treatment (5.6) (Tarkalson et al., 2005). These results indicate that as soil $\mathrm{pH}$ decreases, the rate of acidification decreases in this soil.

The average annual acidification rates for a sampling depth of $15 \mathrm{~cm}$ in this study based on data over 15 years (1989-2003) were lower $(0.68$ and 0.70 for NT(LT) and NT(C), respectively) compared to the average annual acidification rate of the long-term NT acidification rate in the $0-15 \mathrm{~cm}$ depth of 1.7 $\mathrm{kmol} \mathrm{H}^{+} \mathrm{ha}^{-1} \mathrm{yr}^{-1}$, based on data covering 26 years
(1962-1989) at this same site (Table 3) (Tarkalson et al., 2005). This shows that the acidification rate has declined over the past 15 years for the NT(LT) treatment compared to the acidification from 1962 to 1989.

\section{Proton budget}

A proton budget using the theoretical method developed by Helyar and Porter (1989) was applied to this study to assess the causes of acidification and to know the role of each component influencing acidification/alkalinization (Table 4). A total of $23 \mathrm{~kg} \mathrm{~N}$ $\mathrm{ha}^{-1}$ as $\mathrm{AN}$ and $650 \mathrm{~kg} \mathrm{~N} \mathrm{ha}^{-1}$ as UAN was applied to the surface of the plots from 1989 to 2003. The AN and UAN applications added a total of $12.0 \mathrm{kmol}$ of $\mathrm{NH}_{4}^{+}$and $\mathrm{NO}_{3}^{-} \mathrm{ha}^{-1}$, respectively for both the NT(LT) and NT(C) treatments $\left(\mathrm{NH}_{4}{ }^{+}\right.$ad and $\left.\mathrm{NO}_{3}{ }^{-}{ }_{\mathrm{ad}}\right)$ (Table 4). The amount of $\mathrm{NO}_{3}{ }^{-}$and $\mathrm{NH}_{4}{ }^{+}$added in precipitation was assumed to be insignificant.

Accumulation of $\mathrm{NH}_{4}{ }^{+}$and $\mathrm{NO}_{3}-\left(\mathrm{NH}_{4}{ }^{+}\right.$ac and $\mathrm{NO}_{3}{ }^{-}$ac $)$in most aerated soils in the $\mathrm{pH}$ range of 5 to 8 with temperatures above $6{ }^{\circ} \mathrm{C}$ is limited by nitrification and plant uptake (Helyar and Porter, 1989). Ammonium nitrate was applied at a rate of $48 \mathrm{~kg} \mathrm{~N}$ $\mathrm{ha}^{-1}$ from 1962 to 1988 and $23 \mathrm{~kg} \mathrm{~N} \mathrm{ha}^{-1}$ in 1989 to winter wheat and sorghum, and UAN was applied at an average annual rate of $50 \mathrm{~kg} \mathrm{~N} \mathrm{ha}^{-1}$ from 1990 to 2003 to winter wheat and corn. Therefore, the $\mathrm{NH}_{4}^{+}$ and $\mathrm{NO}_{3}^{-}$levels in the soils were likely stable over the long term and there was most likely little accumulation between 1989 and 2003. For this analysis, we assume there was a no significant accumulation of $\mathrm{NH}_{4}^{+}$and $\mathrm{NO}_{3}^{-}$. 
Table 3. Total 14-year and annual acidification rates and the needed $\mathrm{CaCO} 3$ to neutralize the acid for the NT treatments at depths increments of $0-5,5-10,10-15$, and $15-30 \mathrm{~cm}$

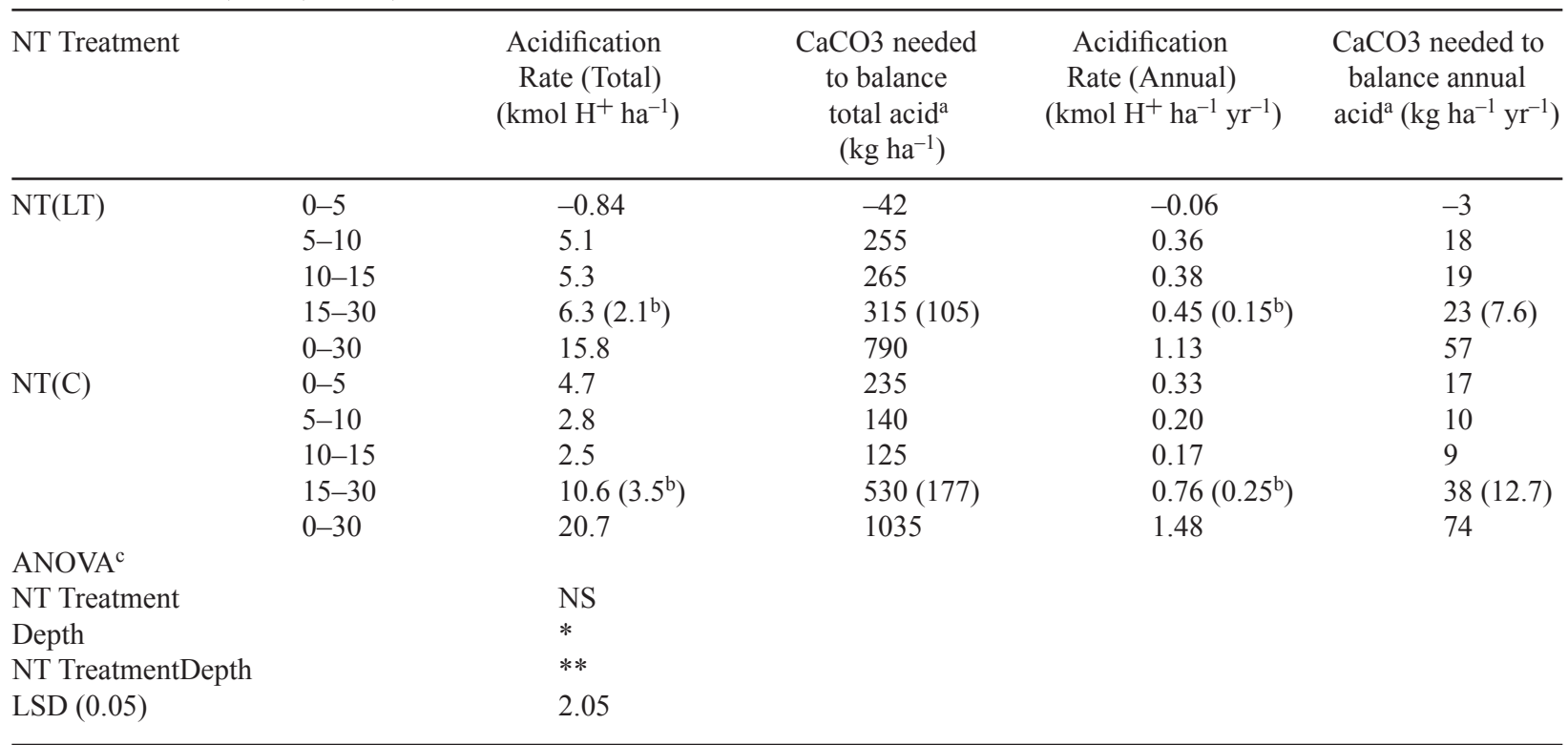

*,** Significant at the 0.05 and 0.01 probability levels, respectively.

${ }^{a}$ Based on $50 \mathrm{~kg} \mathrm{CaCO} 3$ needed to balance $1 \mathrm{kmol}$ acid addition (Ridley et al., 1990).

${ }^{\mathrm{b}}$ Average acidification rate for each $5 \mathrm{~cm}$ depth increment from 15 to $30 \mathrm{~cm}$.

${ }^{\mathrm{c}}$ Data for depth increment of $5 \mathrm{~cm}$ for $15-30 \mathrm{~cm}$ depth used for ANOVA and mean separation.

Table 4. Proton budget for the NT treatments from 1989 to 2003

\begin{tabular}{|c|c|c|}
\hline Acidification Component & $\mathrm{NT}(\mathrm{LT})\left(\mathrm{kmol}(+) \mathrm{ha}^{-1}\right)$ & $\mathrm{NT}(\mathrm{C})\left(\mathrm{kmol}(+) \mathrm{ha}^{-1}\right)$ \\
\hline \multicolumn{3}{|l|}{ Ncycle } \\
\hline$+\mathrm{NH}_{4}^{+}{ }_{\text {ad }}$ & +12.0 & +12.0 \\
\hline$-\mathrm{NO}_{3}{ }^{-}$ad & -12.0 & -12.0 \\
\hline$-\mathrm{NH}_{4}{ }^{+}{ }_{\mathrm{ac}}$ & $-\mathrm{a}$ & - \\
\hline$+\mathrm{NO}_{3}^{-}{ }_{\mathrm{ac}}^{-}$ & - & - \\
\hline$+\mathrm{NO}_{3}^{-{ }^{a} \mathrm{ex}}$ & +26.8 & +35.1 \\
\hline$-\mathrm{NH}_{4}{ }^{+}{ }_{\mathrm{ex}}$ & - & - \\
\hline \multicolumn{3}{|l|}{ C cycle } \\
\hline$+\mathrm{OA}_{\mathrm{ac}}$ & $+(-0.97)$ & $+(-3.6)$ \\
\hline$+\mathrm{OA}_{\mathrm{ex}}$ & +2.4 & +2.3 \\
\hline$-\mathrm{OA}_{\mathrm{ad}}$ & -16.7 & -16.5 \\
\hline \multicolumn{3}{|c|}{ Precipitation and Soil Water Bicarbonate } \\
\hline$+\mathrm{HCO}^{-}{ }_{\text {ex }}$ & +4.3 & +3.4 \\
\hline$-\mathrm{HCO}^{-}{ }_{\text {ad }}$ & -0.14 & -0.14 \\
\hline \multicolumn{3}{|c|}{ Precipitation and Soil Water Acid } \\
\hline$+\mathrm{H}^{+}{ }_{\text {ad }}$ & +0.14 & +0.14 \\
\hline$-\mathrm{H}_{\mathrm{ex}}^{+}{ }_{\mathrm{au}}$ & -0.005 & -0.007 \\
\hline Total Acidification ${ }^{\mathrm{c}}$ & 15.8 & 20.7 \\
\hline
\end{tabular}

${ }^{a}$ Assumed to be negligible.

${ }^{\mathrm{b}}$ Determined by difference [Total acidification rate (equation 1)] ) $\left(\left(\mathrm{NH}_{4}{ }_{\text {ad }}^{+}-\mathrm{NO}_{3}{ }_{\text {ad }}-\mathrm{NH}_{4}{ }_{\mathrm{ac}}+\mathrm{NO}_{3}{ }_{\mathrm{ac}}-\mathrm{NH}_{4}{ }^{+}{ }_{\mathrm{ex}}\right)+\left(\mathrm{OA}_{\mathrm{ac}}+\right.\right.$ $\left.\left.\mathrm{OA}_{\mathrm{ex}}-\mathrm{OA}_{\mathrm{ad}}\right)+\left(\mathrm{HCO}_{3}{ }_{\mathrm{ac}}+\mathrm{HCO}_{3}-{ }_{\mathrm{ex}}-\mathrm{HCO}_{3}{ }_{\mathrm{ad}}\right)+\left(\mathrm{H}^{+}{ }_{\mathrm{ad}}-\mathrm{H}^{+}{ }_{\mathrm{ex}}\right)\right)$.

${ }^{\mathrm{c}}$ Calculated from equation (1). 
The amount of $\mathrm{NH}_{4}{ }^{+}\left(\mathrm{NH}_{4}{ }_{\text {ex }}\right)$ leaching below the $30 \mathrm{~cm}$ depth was considered negligible. The amounts of $\mathrm{NO}_{3}^{-}\left(\mathrm{NO}_{3}^{-}\right.$ex $)$leaching below the $30 \mathrm{~cm}$ depth was determined indirectly by subtracting the overall acidification rate (equation 1) from the sum of all the other constituents of the proton budget (Table 4). Based on the assumptions that $1 \mathrm{kmol} \mathrm{H}^{+}$is equal to $1 \mathrm{kmol} \mathrm{N}$, there were 26.8 and $35.1 \mathrm{kmol}$ $\mathrm{H}^{+} \mathrm{ha}^{-1}$ produced due to nitrate moving below 30 $\mathrm{cm}$ for the NT(LT) and NT(C) treatments over a 14 year time period, respectively. This corresponds to an annual production of 1.9 and $2.5 \mathrm{kmol} \mathrm{H}^{+} \mathrm{ha}^{-1}$. The leaching of $\mathrm{NO}_{3}^{-}$is the main reason for acidification of the soils in this study, representing 59 and $66 \%$ of the $\mathrm{H}^{+}$from acid causing factors in the NT(LT) and NT(C) treatments, respectively . The leaching of $\mathrm{NO}_{3}{ }^{-}$from a soil $(0-25 \mathrm{~cm})$ under wheat production in Australia resulted in an acidification rates ranging from 0 to $1.4 \mathrm{kmol} \mathrm{ha}^{-1} \mathrm{yr}^{-1}$ (Poss et al., 1995). Other sites from this study had a net alkalinization of up to $1 \mathrm{kmol} \mathrm{OH}^{-} \mathrm{ha}^{-1} \mathrm{yr}^{-1}$. They concluded that the factors acidifying the soil under wheat in the semiarid climate were limited because $\mathrm{NO}_{3}{ }^{-}$losses were small and crop residues were retained in the system.

Organic anion accumulation $\left(\mathrm{OA}_{\mathrm{ac}}\right)$ had an alkaline effect on the soil under both the NT(LT) and NT(C) treatments due to a decrease in $\mathrm{OM}$ content from 1989 to 2003 (Tables 1 and 4). The acidifying effect of $\mathrm{OA}_{\mathrm{ex}}$ in harvested grains was $86 \%$ lower than the alkaline additions of $\mathrm{OA}_{\mathrm{ad}}$ from crop residues for both NT treatments on an absolute value basis (Table 4). The average annual yields on the LT(NT) and LT(C) treatments were 2900 and 2860 for wheat, and 6120 and $6080 \mathrm{~kg} \mathrm{ha}^{-1}$ for corn, respectively. Sorghum yields were not measured from 1989 to 1993. The average annual estimated quantity of residue produced on the LT(NT) and LT(C) treatments was 5200 and 5100 for wheat, and 5100 and $6700 \mathrm{~kg} \mathrm{ha}^{-1}$ for corn, respectively. A quantity of $5100 \mathrm{~kg} \mathrm{ha}^{-1}$ was used for annual sorghum residue production based on the average yields from 1983 to 1989 for the LT(NT) and LT(C) treatments (Tarkalson, 2005). Returning the crop residue to the soil helps to counteract the acidity resulting from the leaching of $\mathrm{NO}_{3}{ }^{-}$. If the residue was not returned to the soil due to silage and/or straw production, the acidification rate of this soil could be increased by a maximum of 105 and $78 \%\left(+\mathrm{OA}_{\mathrm{ad}} /\right.$ acidification rate) $\times 100$ ) for the NT(LT) and NT(C). These results collaborate with findings from Poss et al. (1995), who concluded that acidification was minimized in wheat production in semiarid Australia due to crop residues being retained in the system.

Rainfall collected at the research site for the U.S. National Acid Atmospheric Deposition Program has $\mathrm{pH}$ values that are close to the $\mathrm{pH}$ value of $5.67(\mathrm{pH}$ of non-acid rain in equilibrium with atmospheric

Table 5. Annual and total quantity of precipitation and leachate moving below $30 \mathrm{~cm}$

\begin{tabular}{llcc}
\hline Year & Precipitation $(\mathrm{mm})$ & Leached Below $30 \mathrm{~cm}$ depth $(\mathrm{mm})$ & Proportion of Precipitation Leached Below $30 \mathrm{~cm}$ depth \\
\hline 1989 & 269.0 & 20.1 & 0.075 \\
1990 & 328.4 & 47.9 & 0.146 \\
1991 & 402.7 & 134.6 & 0.334 \\
1992 & 474.3 & 110.0 & 0.232 \\
1993 & 578.0 & 270.3 & 0.468 \\
1994 & 427.8 & 161.5 & 0.378 \\
1995 & 416.0 & 84.9 & 0.204 \\
1996 & 646.7 & 496.8 & 0.768 \\
1997 & 397.2 & 177.0 & 0.446 \\
1998 & 438.6 & 56.5 & 0.129 \\
1999 & 495.6 & 189.1 & 0.382 \\
2000 & 391.1 & 168.3 & 0.430 \\
2001 & 564.3 & 202.4 & 0.359 \\
2002 & 185.1 & 32.3 & 0.174 \\
2003 & 318.2 & 239.3 & 0.752 \\
Ave & 422.2 & 159.4 & 0.378 \\
\hline
\end{tabular}


$\mathrm{CO}_{2}$ ) (Helyar and Porter, 1989). The precipitation from 1989 to 2003 averaged $422 \mathrm{~mm} \mathrm{yr}^{-1}$. The total precipitation from 1989 to 2003 was $6333 \mathrm{~mm}$ (Table 5 ). The average percent of precipitation leaching below the $30 \mathrm{~cm}$ depth from 1989 to 2003 was $37.8 \%$ (Table 5). Since both tillage treatments have been under NT since 1989, it was assumed that leaching was similar for both treatments. The $\mathrm{pH}$ of soil water leaving the $30 \mathrm{~cm}$ depth was approximated to be 6.6 and 6.5 for the NT(LT) and NT(C) treatments, respectively. These $\mathrm{pH}$ values were based on the average soil $\mathrm{pH}$ measurements at the $15-30 \mathrm{~cm}$ depth using the soil:water ratio of $1: 1$.

The addition of $\mathrm{HCO}_{3}-$ to the soil in rainfall over the 14 year period was $0.14 \mathrm{kmol} \mathrm{H}^{+} \mathrm{ha}^{-1}$ for both the $\mathrm{NT}(\mathrm{LT})$ and $\mathrm{NT}(\mathrm{C})$ treatments. The export of $\mathrm{HCO}_{3}^{-}$ in the leachate below $30 \mathrm{~cm}$ was 4.3 and $3.4 \mathrm{kmol} \mathrm{H}^{+}$ $\mathrm{ha}^{-1}$ for the NT(LT) and NT(C) treatments, respectively. The rainfall added $0.14 \mathrm{kmol} \mathrm{H}^{+} \mathrm{ha}^{-1}$ over the 14 year period. The export of $\mathrm{H}^{+}$from leachate below the $30 \mathrm{~cm}$ depth was 0.005 and $0.007 \mathrm{kmol} \mathrm{H}^{+}$ $\mathrm{ha}^{-1}$.

\section{Conclusions}

The soils in this study are highly buffered below $\mathrm{pH} 4$ and above $\mathrm{pH}$ 7. The titration curves were similar for both NT treatments at the same depths. The relationships for the titration curves between the $\mathrm{CaCO}_{3}$ and $\mathrm{H}_{2} \mathrm{SO}_{4}$ amendment rates and soil $\mathrm{pH}$ between approximately 4 and 7.3 were significant for both NT treatments at all depths. Correlation coefficients ranged from 0.999 and 1.0. The decreasing buffer capacities with depth were likely a result of decreasing OM content with depth.

There were differences in acidification rates with depth when averaged over the NT treatments but not between NT treatments when averaged over depth. Based on a significant tillage by depth interaction, the acidification rate was higher for the NT(C) treatment compared to the NT(LT) treatment at a depth of 0-5 $\mathrm{cm}$. Based on these data and the fact that the acidification rate has decreased in the past 14 years compared to the previous 26 years (1962 to 1988) the acidification rate decreases as soil $\mathrm{pH}$ decreases in this soil. To neutralize the total acidity in this soil from 1989 to $2003 \mathrm{CaCO}_{3}$ will need to be applied at rates of 57 and $74 \mathrm{~kg} \mathrm{ha}^{-1} \mathrm{yr}^{-1}$ for NT(LT) and NT(C).

The proton budget determined for the $30 \mathrm{~cm}$ depth of this soil indicates that the leaching of $\mathrm{NO}_{3}{ }^{-}$below the $30 \mathrm{~cm}$ depth was the dominant factor in leading to acidification in this soil system. Leaching of $\mathrm{HCO}_{3}^{-}$ also contributed to the acidification of both NT treatments. Other acidity/alkaline influencing factors were minimal to negligible. The added $\mathrm{N}$ fertilizers influenced the acidification of the soil by increasing the quantity of $\mathrm{NO}_{3}^{-}$in the soil which can leach. The alkalinity added to the soil in crop residues neutralized approximately 37 and $31 \%$ of the acid resulting from $\mathrm{NO}_{3}{ }^{-}$losses below the $30 \mathrm{~cm}$ depth and other acid causing constituents for the NT(LT) and NT(C) treatments, respectively. This data shows that residue is a major factor in limiting acidification in this soil production system.

This research shows how soil acidification is occurring on alkaline soils under dry land production systems in the semiarid Great Plains. The acidification of these soils will continue under current management practices and in order to ameliorate potential yield losses in the future, lime additions may be necessary.

\section{References}

Allen R G, Pereira L S, Raes D and Smith M 1998 Crop Evapotranspiration - Guidelines for Computing Crop Water Requirements, Irrigation and Drainage Paper No. 56, FAO, Rome, Italy.

Analytical Software, 2002, Statistix 7, Tallahassee, FL.

Avila-Segura M, Barak P, Posner J L and Laird D A 2000 Coupling of $H$ and $N$ Cycles in Several Common Agroecosystems of Midwestern United States. ASA/CSSA/SSSA Annual Meetings Nov 5-9. Minneapolis, MN. Available at http://www.soils.wisc.edu/ barak/poster_gallery/minneapolis2000/index.html (November 29, 2005).

Barak P, Jobe B O, Krueger A R, Petersen L A and Laird D A 1997 Effects of long-term soil acidification due to nitrogen fertilizer inputs in Wisconsin. Plant and Soil 197, 61-69.

Bolan N S, Hedley M J and White R E 1991 Processes of soil acidification during nitrogen cycling with emphasis on legume based pastures. Plant and Soil 134, 53-63.

Bouman O T, Curtin D, Campbell C A, Biederbeck V O and Ukainetz H 1995 Soil acidification from long-term use of 
anhydrous ammonia and urea. Soil Sci. Soc. Am. J. 59, 1488-1494.

Bowman R A and Halvorson A D 1998 Soil chemical changes after nine years of differential $\mathrm{N}$ fertilization in a notill dryland wheat-corn-fallow rotation. Soil Sci. 163, 241-247.

Dick W A 1983 Organic carbon, nitrogen, and phosphorus concentrations and $\mathrm{pH}$ in soil profiles as affected by tillage intensity. Soil. Sci. Soc. Am. J. 47, 102-107.

Fan X H, Tang C and Rengel Z 2002 Nitrate uptake, nitrate reductase distribution and their relation to proton release in five nodulated grain legumes. Ann. Bot. 90, 315-323.

Heenan D P and Taylor A C 1995 Soil pH decline in relation to rotation, tillage, stubble retention and nitrogen fertilizer in S.E. Australia. Soil Use and Manag. 11, 4-9.

Helling C S, Chesters G and Corey R B 1964 Contribution of organic matter and clay to soil cation-exchange capacity as affected by the $\mathrm{pH}$ of the saturated solution. Soil Sci. Am. Proc. 28, 517-520.

Helyar K R and Porter W M 1989 Soil acidification, its measurement and the process involved. In Soil Acidity and Plant Growth. Ed. A D Robson. pp. 61-102. Academic Press, Sydney.

Helyar K R, Cregan P D and Godyn D L 1990 Soil acidity in New South Wales - current $\mathrm{pH}$ values and estimates of acidification rates. Aust. J. Soil Res. 28, 532-537.

Juo A S R, Dabiri A and Franzluebbers K 1995 Acidification of a kaolinitic Alfisol under continuous cropping with nitrogen fertilization in West Africa. Plant and Soil 171, 245-253.

Lilienfein J, Wilcke W, Vilela L, Lima S D, Thomas R and Zech W 2000 Effect of no-till and conventional tillage systems on the chemical composition of soils solid phase and soil solution of Brazilian savanna oxisols. J. Plant Nutr. Soil Sci. 163, 411-419.

Lindsay W L 1971 Chemical Equilibria in Soils. John Wiley and Sons, New York.

Magdoff F R and Bartlett R J 1985 Soil pH buffering revisited. Soil Sci. Soc. Am. J. 49, 145-148.
Mahler R L and Harder R W 1984 The influence of tillage methods, cropping sequence, and $\mathrm{N}$ rates on the acidification of a northern Idaho soil. Soil Sci. 137, 52-60.

McCarthy J R, Pfost D L, Currence D 1993 Conservation Tillage and Residue Management to Reduce Soil Erosion. University of Missouri Extension, available at http://muextension.missouri.edu/xplor/agguides/agengin/g01650.htm

Nelson D W and Sommers L E 1982 Total carbon, organic carbon, and organic matter. In Methods of Soil Analysis, Part 2. Agron. Monogr. 9. Ed. A L Page. pp. 539-579. 2nd edition, ASA, Madison, WI.

Pierre W H and Banwart W L 1973 Excess-base and excessbase/nitrogen ratios of various crop species and plant parts. Agron. J. 65, 91-96.

Poss R, Smith C J, Dunin F X and Angus J F 1995 Rate of soil acidification under wheat in a semi-arid environment. Plant Soil 177, 85-100.

Ridley A M, Helyar K R and Slattery W J 1990 Soil acidification under subterranean clove (Trifolium subterraneum L.) pastures in north-eastern Victoria. Aust. J. Exp. Ag. 30, 195-201.

Tang C, Rengel Z, Raphael C and Bowden J W 2000 Understanding subsoil acidification: effect of nitrogen transformation and nitrate leaching. Aust. J. Soil Res. 38, 837-849.

Tarkalson D D, Hergert G W, Cassman K G 2005 Soil Chemical Properties and Grain Yields of a Dry Land Winter Wheat-Ecofallow-Sorghum/Corn-Fallow Rotation Under No-Till and Conventional-Till. Agron. J. in press.

Wicks G A, Smika D E and Hergert G W 1988 Longterm effects of no-tillage in a winter wheat (Triticum aestivum)sorghum (Sorghum bicolor)-fallow rotation. Weed Sci. 36, 384-393.

Wicks G A, Stahlman P W and Anderson R L 1995 Weed management systems for semiarid areas of the central Great Plains. Proc. North Central Weed Sci. Soc. 50, 174-190.

Wright J L 1982 New evapotranspiration crop coefficients. $J$ Irr. Drain. Div. ASCE. 108, 57-74. 